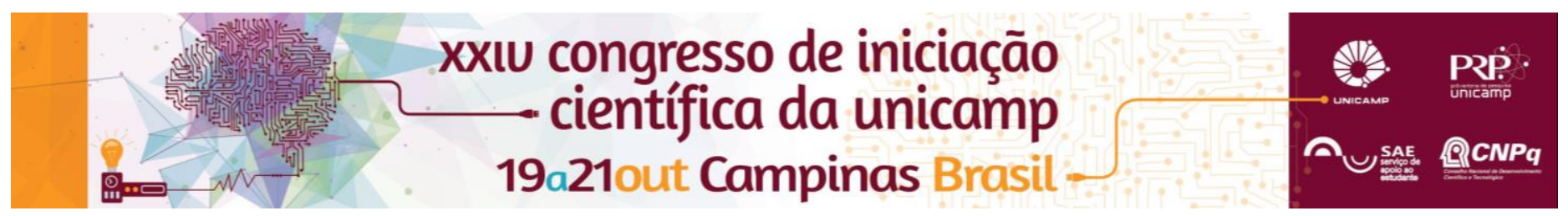

\title{
QUANTO AS PANELAS DE ALUMÍNIO CONTRIBUEM COM O ALUMÍNIO PRESENTE NO LODO DE ESTAÇÕES DE TRATAMENTO DE ESGOTOS
}

\author{
Amanda dos Santos Silva (IC), Bruna Luiza Martins Marconato (IC), Adriano Luiz Tonetti (PQ).
}

\section{Resumo}

Diversas caracterizações de lodo de estações de tratamento de esgotos apontam para uma relevante presença de alumínio (Al) em sua composição. Acredita-se que uma das fontes contribuintes para encontrarmos uma parcela desse elemento no lodo venha do uso de utensílios de cozinha compostos por esse metal. Logo, o objetivo deste projeto é avaliar a possibilidade da presença de alumínio no lodo das Estações de Tratamento de Esgoto (ETE) seja proveniente do uso residencial de panelas de alumínio.

\section{Palavras-chave:}

Panelas de alumínio, Lodo, Efluente doméstico

\section{Introdução}

O Alumínio (Al) é um dos metais mais abundantes na crosta terrestre, portanto ele é encontrado de diversas formas na natureza. Devido sua fartura na superfície terrestre e características físico-químicas como, por exemplo, a resistência a corrosão, esse metal tornou-se atrativo para as indústrias ${ }^{1}$.

Há uma diversidade de utensílios domésticos e embalagens feitas com Al. Estudos indicam que o contato crônico com o Al, por causa dos utensílios de cozinha, pode acarretar em distúrbios neurológicos como o Alzheimer. Entretanto, ainda se sabe pouco sobre os possíveis efeitos deletérios provenientes do contato e ingestão desse metal.

Pesquisas recentes do Departamento de Saneamento e Ambiente (DSA) da Faculdade de Engenharia Civil (FEC, UNICAMP) encontraram relevantes índices de Al na base sólida do lodo da ETE de Coronel Machado - SP, conforme mostra na tabela abaixo.

Tabela 1. Caracterização da Base Seca do Lodo da ETE de Coronel Macedo (SP)

\begin{tabular}{|c|c|c|}
\hline & Parâmetros & Resultado (base seca) \\
\hline \multirow{5}{*}{$\begin{array}{l}\text { Exemplo de } \\
\text { Caracterização }\end{array}$} & Nitrogênio amoniacal & 955 \\
\hline & Nitrogênio nitrato-nitrito & 39,5 \\
\hline & Nitrogênio total & 14,2 \\
\hline & Alumínio* & 12175 \\
\hline & Bário* & 260 \\
\hline & Cádmio* & 0,60 \\
\hline \multirow{4}{*}{$\begin{array}{c}\text { ETE de Coronel } \\
\text { Macedo (SP) }\end{array}$} & Cálcio* & 6,1 \\
\hline & Chumbo* & 37,5 \\
\hline & Ferro* & 19407 \\
\hline & Fósforo* & 3,7 \\
\hline Fonte. Nope & $\begin{array}{l}\text { Mercúrio* } \\
\text { hi Silva }^{2}\end{array}$ & $<1,0$ \\
\hline
\end{tabular}

Porém, a problemática relacionada com esse metal não foi desenvolvida, visto que a legislação vigente para a aplicação de lodo na agricultura (CONAMA no 375 de 2006) ${ }^{3}$ não traz a tona as possíveis implicações desse metal em excesso no solo. Devido ao fato de ser uma substância organoléptica, ou seja, possuir características que podem ser percebidas pelos sentidos humanos, somente na portaria de potabilidade da água do Ministério da Saúde, ํo 2914 de 2011 é possível encontrar valores máximos permitidos desse metal $(0,2 \mathrm{mg} / \mathrm{L})$.
Logo, como objetivo desse projeto busca-se avaliar a possibilidade da presença de alumínio no lodo das Estações de Tratamento de Esgoto (ETE) seja proveniente do uso residencial de panelas de alumínio.

\section{Metodologia}

Um questionário será aplicado à comunidade acadêmica da UNICAMP a fim de traçar perfis de lavagem de panelas e quantificar o uso de panelas de alumínio. As questões permitirão que tracemos perfis de lavagem das panelas de alumínio.

O questionário conta com doze questões tais como: Quantas panelas você tem em sua casa? Com que frequência você utiliza panelas de alumínio no preparo dos alimentos em sua residência? Quanto tempo você gasta na lavagem de uma panela?

Os dados obtidos servirão para traçarmos se há tendências de lavagem de panelas e caso haja, como elas influenciam os teores de alumínio observados na ETE Barão Geraldo.

\section{Resultados Esperados}

A partir da aplicação do questionário espera-se estipular qual é a porcentagem de alumínio liberado por panelas alumínio em relação a população da região Barão Geraldo. Assim, uma possível relação de causa e efeito será proposta visando identificar as fontes que contribuam para encontrarmos valores relevantes desse metal encontrado no lodo de ETEs.

\footnotetext{
CONRADO, J. M. Determinação do teor de alumínio absorvido pela água deionizada, após fervura em panelas fabricadas com o metal. Centro Universitário de Formiga, 2014.

${ }^{2}$ SILVA, N. B. Avaliação química e ecotoxicológica de lodos de esgoto visando à utilização na agricultura. UNICAMP, 2012.

${ }^{3}$ CONAMA, Resolução no 375, de 26/09/2006. Brasil: Diário Oficial da União.

${ }^{4}$ Ministério da Saúde. Portaria no 2914, de 12/12/2011.
} 